\title{
Constructing cartographic authority: the conceptualization and mapping of urban spaces in Edinburgh, c. 1880 - c. 1920
}

\author{
ANNA FEINTUCK \\ School of History, Classics and Archaeology, William Robertson Wing, Old \\ Medical School, Teviot Place, Edinburgh, EH8 9AG, UK
}

\begin{abstract}
This article examines how, in the production and use of cartographic items, urban space and local knowledge were brought together to construct authoritative representations of place. Its approach is twofold. The first half of the article is an examination of the mapmakers John Bartholomew \& Co.'s changing premises across Edinburgh, which shows that the firm carefully curated their business properties in order to convey credibility and gain trust. The article then introduces the London-based firm Charles E. Goad Ltd, producers of fire insurance plans, and considers their acquisition of urban information and their use of local knowledge from a distance to achieve similar aims. Both cases illustrate the importance of close attention to geography and the spatial dimensions of knowledge construction.
\end{abstract}

\section{Introduction}

Mapmaking is a practice inherently embedded in the local context. An exceptionally high degree of local knowledge is required to produce an accurate, authoritative representation of place. In the late nineteenth century, as cities grew rapidly and understanding the nature of contemporary urbanism became a key concern for city officials, engineers, planners and more, cartography developed in line with the increasing complexity of urban space. The relationship between the map and the city is, however, more dynamic than this. This is aptly illustrated through the example of Edinburgh-based mapmakers John Bartholomew \& Co., who were well aware that cartographic authority relied on socially produced credibility as well as straightforward accuracy or 'truth'. As a multigenerational family firm, they held a long-standing knowledge of the city that served a range of interlinked purposes. The following analysis demonstrates that their deep understanding of Edinburgh allowed them to advance their corporate reputation far beyond the city, not only through the production of credible maps, but also through the reinforcement of 
an image of Edinburgh as a cultural, intellectual place. From London, meanwhile, Charles E. Goad Ltd, producers of fire insurance plans, employed a similar authority-building rhetoric through the use of local collaboration. Whether on the ground or at a distance, this article shows that cartographic items and their reputations were produced socially as well as materially.

The local conditions in which knowledge was made are crucial to understanding its nature, along with its subsequent circulation and reception. This is apparent in the activities of both Bartholomew and Goad. Each firm relied heavily on various aspects of locality to construct their reputation and, in so doing, enhance the credibility of their maps and plans. This focus on locality appears to counter the idea of knowledge being produced, primarily, in established 'truth-spots': that is, apparently 'placeless places', which encourage the belief that 'claims from there are true anywhere'. ${ }^{1}$ Truth-spots and their supposed universality are, however, always constructed: Thomas Gieryn exposes the effort inherent in doing so. ${ }^{2}$ Knowledge production, therefore, is viewed here not as placeless but as fundamentally situated. This renders practicalities, such as the availability of a suitable workforce, significant; discursive strategies for validation and reputation building are not wholly sufficient explanations. Furthermore, the production of cartographic knowledge is distinctive, because of the extent of place-specific knowledge it demands. For cartographic firms to embed their image firmly in the urban context, then, reflects the particular expertise of the profession, rather than rendering output inauthentic through close connection to place.

It is productive to think of the 'site, region and circulation' of scientific knowledge, or, more simply, to consider it in terms of its production and consumption 'in place', and its movement 'over space'. ${ }^{3}$ This includes the places in which knowledge was physically produced as well as 'discursive sites' where it was made significant, validated or contested. ${ }^{4}$ The studies of Bartholomew and Goad presented here operate across multiple scales: Bartholomew's premises can be seen as a 'site' of knowledge, and the contemporary conceptualization of their architectural features is shown to be telling. Alongside this, the city of Edinburgh itself played a crucial role in establishing credibility and thus allowing cartographic knowledge

1 T.F. Gieryn, 'Three truth-spots', Journal of the History of the Behavioral Sciences, 38 (2002), 113; T.F. Gieryn, 'City as truth-spot: laboratories and field-sites in urban studies', Social Studies of Science, 36 (2006), 6.

2 Ibid.

${ }^{3}$ D.N. Livingstone, Putting Science in its Place (Chicago and London, 2003), 14; C.W.J. Withers and D.N. Livingstone, 'Thinking geographically about nineteenth-century science', in D.N. Livingstone and C.W.J. Withers (eds.), Geographies of Nineteenth-Century Science (Chicago and London, 2011), 3. On movement, see also J. Secord, 'Knowledge in transit', Isis, 95 (2004), 654-72.

4 P. Galison and C.A. Jones, 'Factory, laboratory, studio: dispersing sites of production', in P. Galison and E.A. Thompson (eds.), The Architecture of Science (Cambridge, MA, and London, 1999), 498. 
to circulate on a national and global scale. An intuitive and sometimes tacit knowledge of the city was at play here. Focusing on Goad's plans of Edinburgh, meanwhile, allows the city to be considered as both subject and object of the formation of cartographic and spatial knowledge. Through the production of highly detailed fire insurance plans, the architectural features of individual sites across the city were cartographically realized. In this case, the knowledge employed was meticulously sourced from local industry professionals. Each firm developed context-specific but nonetheless generalizable methods, in which close attention to locality was key. Both cases, moreover, offer a broader illustration of the nature of contemporary urbanism, reinforcing arguments that the city was increasingly documented, governed, rationalized and made legible during the late nineteenth century. ${ }^{5}$

\section{Mapmaking premises and the architecture of cartographic knowledge}

In the late nineteenth and early twentieth centuries, print was the conventional means of establishing claims of knowledge. ${ }^{6}$ The expression of epistemological credibility, however, can take many forms. Mapmaking premises, as sites of physical production processes, served as vehicles for getting knowledge into print, but were also agents in the formation of validity and authoritative knowledge. In cartography, such values were based upon the accuracy and utility of the map in question. This should not be seen simply in terms of the end product. Notions of accuracy and precision imbued every stage of the mapmaking process.

Buildings are one stage in this process, and a vital one for forming identity and constructing authority. Bartholomew's changing premises across Edinburgh became internally ordered, with departments occupying separate rooms or floors, and were also conceptualized, documented and insured in a systematic manner. This demonstrates, in part, a need for space to accommodate more complex procedures, such as advanced printing techniques, and shows that the premises played a role in establishing the nature of the firm's physical output. This relationship, however, also operates on an epistemic level. Just as maps became more accurate - or at least more self-consciously accurate - in their representations of space so, too, were buildings and their contents considered in a more rational, methodical way. Changes in the structure of buildings, attitudes towards them and the cartographic products made

${ }^{5}$ The legibility of the city is the central point in K. Lynch, The Image of the City (Cambridge, MA, 1960). It has since been used by a number of urban historians. See, for example, P. Joyce, The Rule of Freedom: Liberalism and the Modern City (London and New York, 2003), 55; E. Hanna, 'Seeing like a cyclist: visibility and mobility in modern Dublin, c. 1930-1980', Urban History, 42 (2015), 273.

${ }^{6}$ Withers and Livingstone, 'Thinking geographically', 11. 
within them all demonstrate how attention to space illuminates the social as well as physical production of knowledge. The urban environment is shown here to play a crucial, dynamic role in making cartographic knowledge credible and thus allowing it to circulate. Mapmakers may not have worked in laboratories, or other sites traditionally considered as places of knowledge production, but their premises were nonetheless, like larger-scale industrial works, sites of 'invention and intervention'.7

Location played an important role in establishing reputation and credibility. ${ }^{8}$ Knowledge's 'irremediably local dimension' could be manipulated through the careful siting of business premises to garner trust. ${ }^{9}$ In March 1889, Bartholomew moved from their premises at 7 Brown Square - later known as 31 Chambers Street - to the Parkside Works: larger, purposebuilt premises in the south-east of Edinburgh, rented from the printer and publisher Thomas Nelson \& Co. They stayed at Parkside until 1911 when they moved to a site on Duncan Street, just a few streets away. Prior to 1888, the firm had been resident at East St James Street and 4 North Bridge, both on the northern edge of Edinburgh's Old Town. This steady move south across the city corresponds directly with the firm's growth. Their workforce more than doubled, for example, between the 1880s and 1930s, with many employees residing close by in the city's 'southside'. ${ }^{10}$ Away from the congested Old Town, increasingly spacious and industrially equipped premises were available. This was a conscious decision on Bartholomew's part: the notice to sell or let the premises at 31 Chambers Street described the firm's intention to move to 'new and more extensive works'. ${ }^{11}$ Likewise, Nelson's advertisement for the Parkside Works, produced after Bartholomew announced an intention to move, explained that the previous occupants 'have found it necessary to build larger works in the neighbourhood'. ${ }^{12}$ In terms of industry connections, printing and publishing was prevalent throughout the city centre, as shown in Figure 1, but Bartholomew were not the only firm to see the appeal of this area: 77 firms in a variety of related trades could be found within one mile of the Duncan Street premises. This meant they were close to their collaborators and suppliers. Nelson, for example, remained a key commissioner of maps for atlases throughout the twentieth century. These economic and practical considerations were an important part of

7 P. Miller and T. O'Leary, 'The factory as laboratory', Science in Context, 7 (1994), 470; Gieryn, 'City as truth-spot', 28.

8 See, for example, S. Forgan, 'Building the museum: knowledge, conflict and the power of place', Isis, 96 (2005), 583; S. Forgan and G. Gooday, 'Constructing South Kensington: the buildings and politics of T.H. Huxley's working environments', British Journal for the History of Science, 29 (1996), 438.

9 A. Ophir and S. Shapin, 'The place of knowledge: a methodological survey', Science in Context, 4 (1991), 4.

10 National Library of Scotland (NLS), Bartholomew Archive (BA), Acc.10222/BR/500-10, wages books, 1888-1939.

11 NLS, BA, Acc.10222/BR/251b, Brown Square papers, notice to let or sell, 1889.

12 NLS, BA, Acc.10222/BR/252, Parkside papers, notice to let on lease, 1911. 


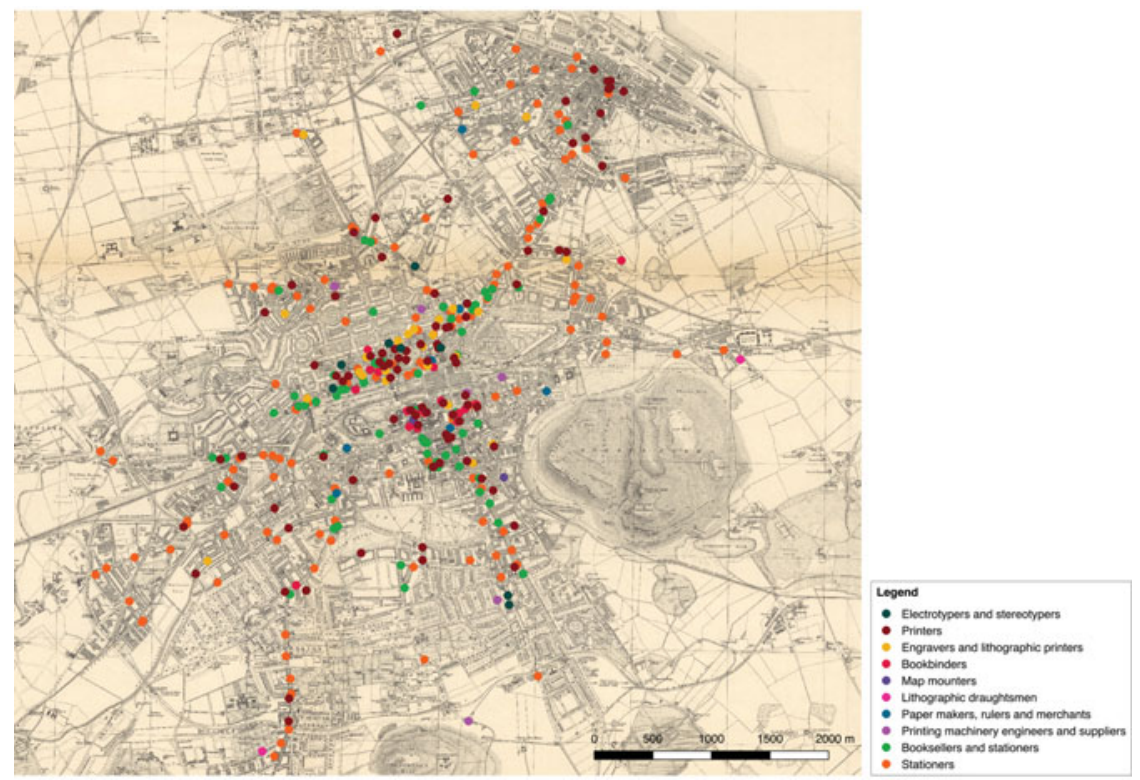

Figure 1: (Colour online) Map showing the distribution of printing and publishing trades in Edinburgh, 1900.

Data: Post Office Edinburgh and Leith Directory 1900-01 (Edinburgh, 1901). Base map: J.G. Bartholomew, Bartholomew's Plan of Edinburgh and Leith with Suburbs Constructed from Ordnance and Actual Surveys (1902), National Library of Scotland, Acc.10222/PR/32b fo. 120. Reproduced with permission of the Trustees of the National Library of Scotland.

the decision to move, but were not the only factors. The reputation of the locality also formed part of the appeal.

The reception and credibility of scientific work could be shaped by how its reader or user imagined its place of provenance. ${ }^{13}$ John George Bartholomew (hereafter JGB), third-generation head of the firm, was fully aware of this factor, and knew the locality well. His personal, lifelong experience of Edinburgh bestowed authority - what Gieryn terms 'credibility through nativity'. ${ }^{14}$ In 1887, JGB helped to compile a report on the 'Newington and Grange' area, under which category both Parkside and Duncan Street fall, as part of his role as a director in the Warrender Private Baths Company. This report aimed to justify the building of swimming baths, but its content has broader significance. It described the district as 'populous and influential' and notes that 'the number of

${ }^{13}$ D.N. Livingstone, 'Politics, culture, and human origins: geographies of reading and reputation in nineteenth-century science', in Livingstone and Withers (eds.), Geographies of Nineteenth-Century Science, 180.

14 Gieryn, 'Three truth-spots', 115. 
dwelling-houses with a rental of $£ 30$ and upwards, in the Newington and St Cuthbert's Wards alone, is $3232{ }^{\prime}{ }^{15}$ With this information in mind, as well as JGB's tacit urban knowledge, when the time came to move from Parkside, the firm had no intention of leaving the area. Plans and drawings show that a nearby site on Grange Loan was also under consideration. ${ }^{16}$ When the Duncan Street premises came up for sale in the spring of 1908, Bartholomew quickly secured them. Negotiations followed with the city council relating to the precise positioning of the building. In a Dean of Guild petition (against setting the building further back from the road than the firm desired), Bartholomew's solicitors appealed to the council's sympathy by declaring that the firm had 'been searching for a suitable site for over two years, and have found great difficulty in getting one at all in the locality'. ${ }^{17}$ There is an implication here that the firm went to considerable lengths to secure this property, based on a strong desire to be in this specific area. Evidently, JGB was aware of the particularity of place and prepared to use this to the firm's advantage.

The trust of those outside a building played a role in warranting 'the credibility of claims made inside'.$^{18}$ Bartholomew used various means to acquire this trust, including the design of their premises. In this case, the form of the building reflected Bartholomew's desire for intellectual prestige rather than conveying an impression of the light industrial action taking place inside. Despite being designed by architects from the same practice, Bartholomew's Duncan Street premises (see Figures 2 and 3) were visually distinct from Parkside. The former includes a neo-classical temple-front portico transposed onto a fairly simple two-storey façade with projecting wings at each end. It was, and remains, visibly different in style to the buildings that surround it, both on Duncan Street itself and the adjoining Causewayside. At Parkside, by contrast, Bartholomew were resident in a long, low building with elements of Scottish Baronial styling such as turrets with candle-snuffer conical roofs, tourelles with small, narrow windows redolent of a gun-opening and crow-stepped gabling. This was typical of similar firms in the city.

When presented with the opportunity to create purpose-built premises, JGB showed a desire to differentiate the firm from other printers and publishers in the city. The Duncan Street premises were strikingly grand considering a large proportion of the building housed industrial processes. The front portico plays a significant role in creating this impression. This section of the building was originally built as part of the façade of Falcon Hall, in Edinburgh's prosperous Morningside area, which the Bartholomew family rented in the early twentieth century. When Falcon

${ }^{15}$ NLS, BA, Acc.10222/BR/45, John George Bartholomew's financial documents, shareholdings in Warrender Private Baths Company, 14 Mar. 1887.

16 NLS, BA, Acc.10222/BR/252, Parkside papers, sketch of proposed Grange Loan site.

17 NLS, BA, Acc.10222/BR/261, Duncan Street papers, letter to Thomas Hunter, town clerk, 24 May 1909.

18 Livingstone, Putting Science in its Place, 29. 


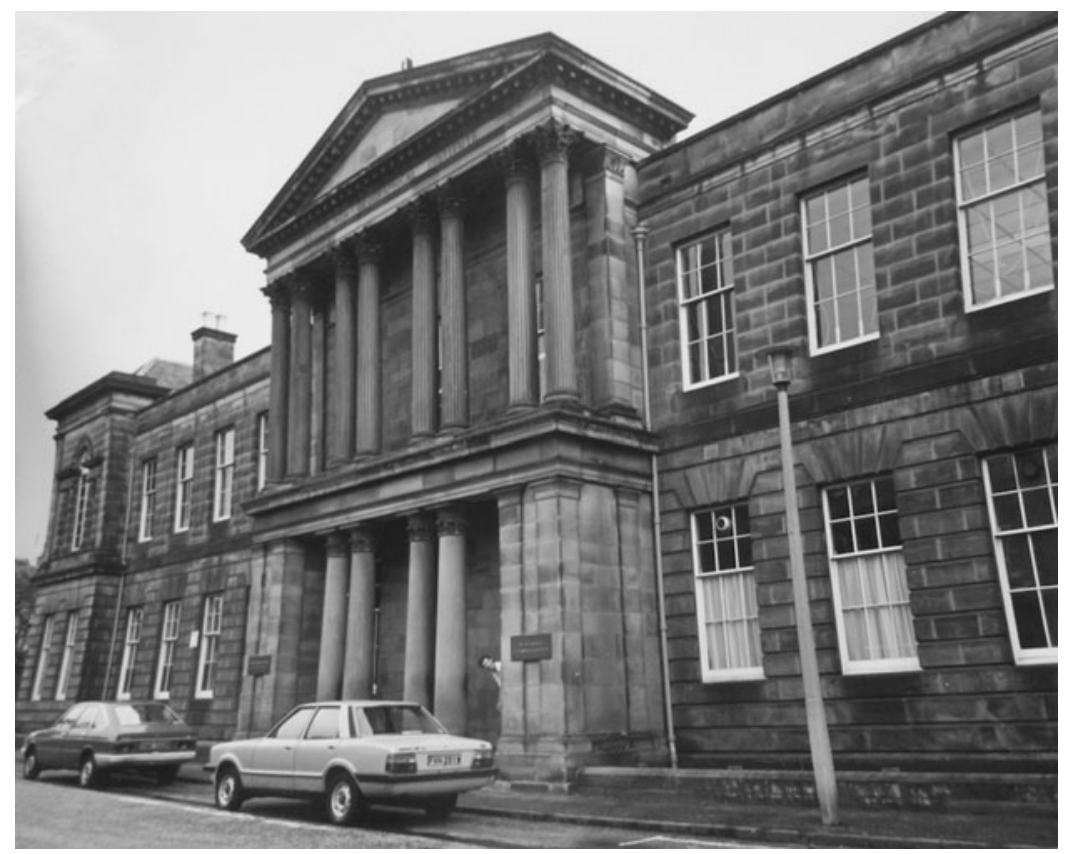

Figure 2: Exterior of Edinburgh Geographical Institute, Duncan Street entrance, 1981. The frontage is unchanged from its original design in 1909. The portico was moved directly from Falcon Hall.

Source: National Library of Scotland, Acc.10222/BR/269, drawings and photographs of premises. Reproduced with permission of HarperCollins Publishers.

Hall was demolished to erect tenements in 1909, JGB offered a local builder $£ 275$ to move the portico in order for it to be incorporated into Duncan Street's design. ${ }^{19}$ Here, Bartholomew again mixed personal and business interests. The portico had been part of a beloved family home, and there is an element of nostalgia to be found in Bartholomew's desire to re-erect it. There are also elements of conscious business-mindedness: away from a relationship with Nelson, perhaps (the two firms were in a formal co-partnership between 1888 and 1892, after which their relationship was that of tenant and landlord). This corresponds broadly with a period in which Bartholomew began publishing more maps in their own name, rather than relying on commissions from other publishers. This suggests an independent-minded approach to business, as well as

19 NLS, BA, Acc.10222/BR/260, Duncan Street papers, letter from J.M. Cruickshank to J.G. Bartholomew, 6 Oct. 1908. 


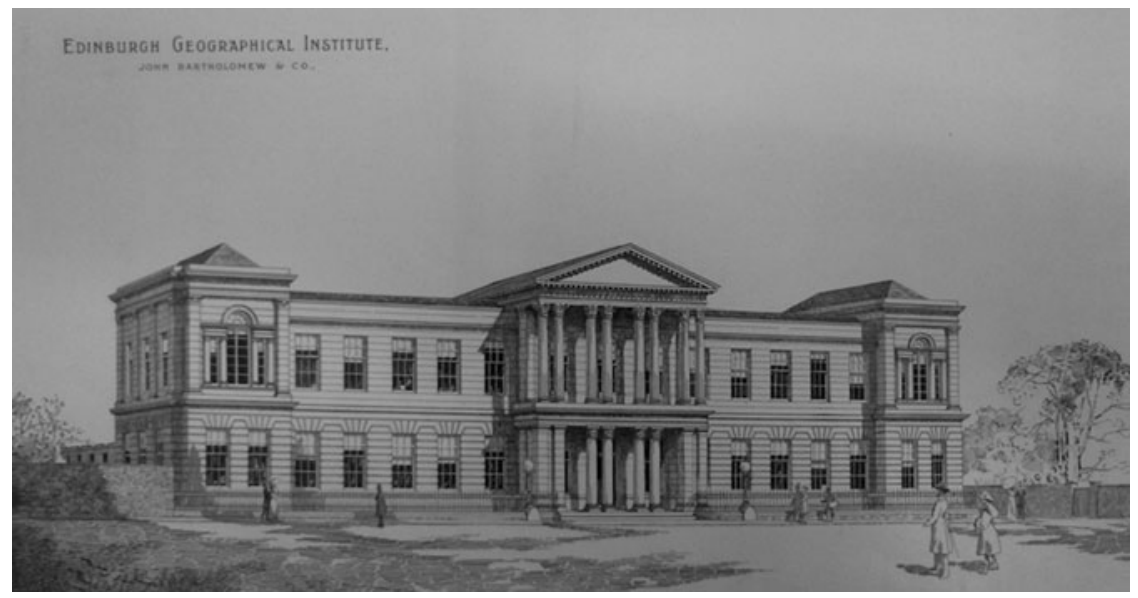

Figure 3: Architect's impression of the Edinburgh Geographical Institute, Bartholomew's Duncan Street premises. An image similar to this was used as Bartholomew's letterhead from March 1911.

Source: National Library of Scotland, Acc.10222/BR/266, engravings of Duncan Street premises. Reproduced with permission of HarperCollins Publishers.

reflecting the paternalistic management style common in late nineteenthcentury Scotland. ${ }^{20}$

Bartholomew were acutely aware of the importance of reputation. JGB needed a site that demonstrated his firm's burgeoning worldwide standing and his own institutional and associational accolades. ${ }^{21}$ The Duncan Street premises, tellingly named the Edinburgh Geographical Institute (hereafter EGI), which itself placed an emphasis firmly on intellectualism, were designed to set his firm apart from other printers and publishers in the city. An image commissioned by the firm shortly after its building shows the premises set in what appears to be parkland more redolent of the Falcon Hall estate (see Figure 3). This is a rare example of explicit disconnect from the urban environment, which otherwise constituted a crucial part of the firm's identity formation. In reality, the EGI was one part of a road of buildings. In both imaginings and in reality, however, the façade of the building does not suggest that industrial activity took place inside. The implication, rather, is of grandeur and

20 NLS, BA, Acc.10222/BR/313-22, order and cost books, 1886-1944.

21 JGB held a range of public positions and associational honours relating to geography and cartography. He was a founding member of the Royal Scottish Geographical Society in 1884 , and remained its honorary secretary his whole life; was elected a fellow of the Royal Society of Edinburgh in 1887, and of the Royal Geographical Society in 1888; was awarded an honorary degree from the University of Edinburgh in 1909, commemorated in a portrait by Edward Arthur Walton, and was geographer and cartographer to King George V. 
elegant professionalism - and, for those who knew the story of the portico, the intermingling of personal and business concerns.

Different kinds of architecture presuppose different kinds of inhabitant. $^{22}$ The design of the EGI accurately reflected the intellectual nature of the work carried on within, along with Bartholomew's paternalistic, family-oriented management, but not necessarily the physical aspects of mapmaking. Instead, it emphasized intellectualism and thus aimed to construct authoritative representations of the value of the firm's output. If truth-spots can be formed through skilled literary rhetoric, here visual rhetoric is at play: architecture as a display of commercial and reputational power. ${ }^{23}$ As was the case with the decisions over location, the design aimed to establish an independent status and, through neo-classical references, give architectural credibility to cartographic practice.

If visitors to Bartholomew's premises saw mapmaking in action, and watched the accuracy and precision with which employees worked in other words, if the building had served as a 'demonstrative truthspot' - they would potentially have acquired a clear understanding of (and thus, according to such theories, an augmented belief in) the finished product. ${ }^{24}$ Instead, publicly visible elements of cartographic production were separate from industrial activity. Visitors saw a grand foyer and meeting rooms rather than printing presses. This implies that the cultural and social aspects of mapmaking were those Bartholomew wished to emphasize in visitors' immediate impressions. These impressions were closely curated: interaction was crucial to establishing reputation and authority. The internal design of a building was often manipulated in order to articulate its inhabitants' key philosophies. ${ }^{25}$ The development of separate entrances for members of the public and employees, for example, can be seen to reflect increasing professionalization in business. ${ }^{26}$ In mapmaking, this shows the development of the strong social and institutional connections that JGB had. Personal and business relationships formed an important part of the culture of cartography, as was the case with other aspects of scientific culture in this period. ${ }^{27}$ The following discussion focuses on floor plans of Parkside and the Duncan Street premises to show that this aspect of mapmaking was largely conducted separately from the physical, industrial processes carried out within the buildings.

${ }^{22}$ P. Galison, 'Buildings and the subject of science', in Galison and Thompson (eds.), The Architecture of Science, 2.

23 Gieryn, 'Three truth-spots', 118.

${ }^{24}$ Ibid., 124.

${ }^{25}$ Livingstone, Putting Science in its Place, 35-7, discusses this in the context of Patrick Geddes' Outlook Tower in Edinburgh (1892).

${ }^{26}$ S. Forgan, "'But indifferently lodged...": perception and place in building for science in Victorian London', in C. Smith and J. Agar (eds.), Making Space for Science: Territorial Themes 27 Ibid. 
Entrances are especially telling: they make a building's intended entrants clear. ${ }^{28}$ At Parkside, visitors entered through a decorated doorway underneath a circular tower on the corner of two main roads. The entrance hall itself was octagonal with tiled marble flooring. ${ }^{29}$ The entrance for employees, by contrast, was at the rear of the building, off Parkside Terrace. It took the employee past three small cloakrooms and directly into the machine room, the largest and noisiest room on the premises, where the bulk of staff were employed: in 1900, 33 employees worked in the machine room, whereas engraving, the next largest department, had 17 employees. ${ }^{30}$ At Duncan Street, the official entrance was a doorway set into the grand portico from Falcon Hall. As was the case at Parkside, floor plans show that employees entered through a different door, this time around the corner on South Gray Street, undecorated and roughly one third of the width of the main entrance (see Figure 4). These separate entrances could be conceptualized as epitomizing the 'front' and 'back' of the business: for visitors and for workers, respectively. ${ }^{31}$ It follows that the 'front' of a business can be a performative space, where desired identities are acted out or visually represented..$^{32}$ While the official entrance took the visitor, in both cases, into a grand entrance hall designed to demonstrate the firm's global standing, the workers' entrance took employees straight to work, via only a cloakroom. This separation amply illustrates two sides of mapmaking in this period, namely intellectual and industrial activity. This was a clear move away from Bartholomew's practice 30 years previously: insurance documents from the property at 31 Chambers Street describe the fittings and furnishings of the lobby as being simply 'two wheelbarrows' ${ }^{33}$ The level of detail supplied for other rooms in the Chambers Street premises such as the precise quantity of inkbottles in the office - suggests this was a careful and broadly accurate report. It seems, then, that upon their move to purpose-built (albeit rented) premises at Parkside, Bartholomew made a decision to give the building a suitable public face in the form of an official entrance. This move towards professionalization was continued at Duncan Street, where the grand entranceway reflected the firm's growing reputation and ambition.

Although entrance systems were broadly similar at Parkside and Duncan Street, the interiors of the buildings differed considerably. The respective footprints of the two buildings give the impression that the Parkside Works were roughly the same size as the premises on Duncan

28 T.F. Gieryn, 'Two faces on science: building identities for molecular biology and biotechnology', in Galison and Thompson (eds.), The Architecture of Science, 431.

29 NLS, BA, Acc.10222/BR/252, Parkside papers, notice to let on lease, 1911.

30 NLS, BA, Acc.10222/BR/504, wages book, 1898-1901.

31 Forgan, "“But indifferently lodged..."', 577.

32 Gieryn, 'Two faces on science', 425.

33 NLS, BA, Acc.10222/BR/238, inventories and valuations, valuation of fittings at 31 Chambers Street, 30 Jun. 1888. 


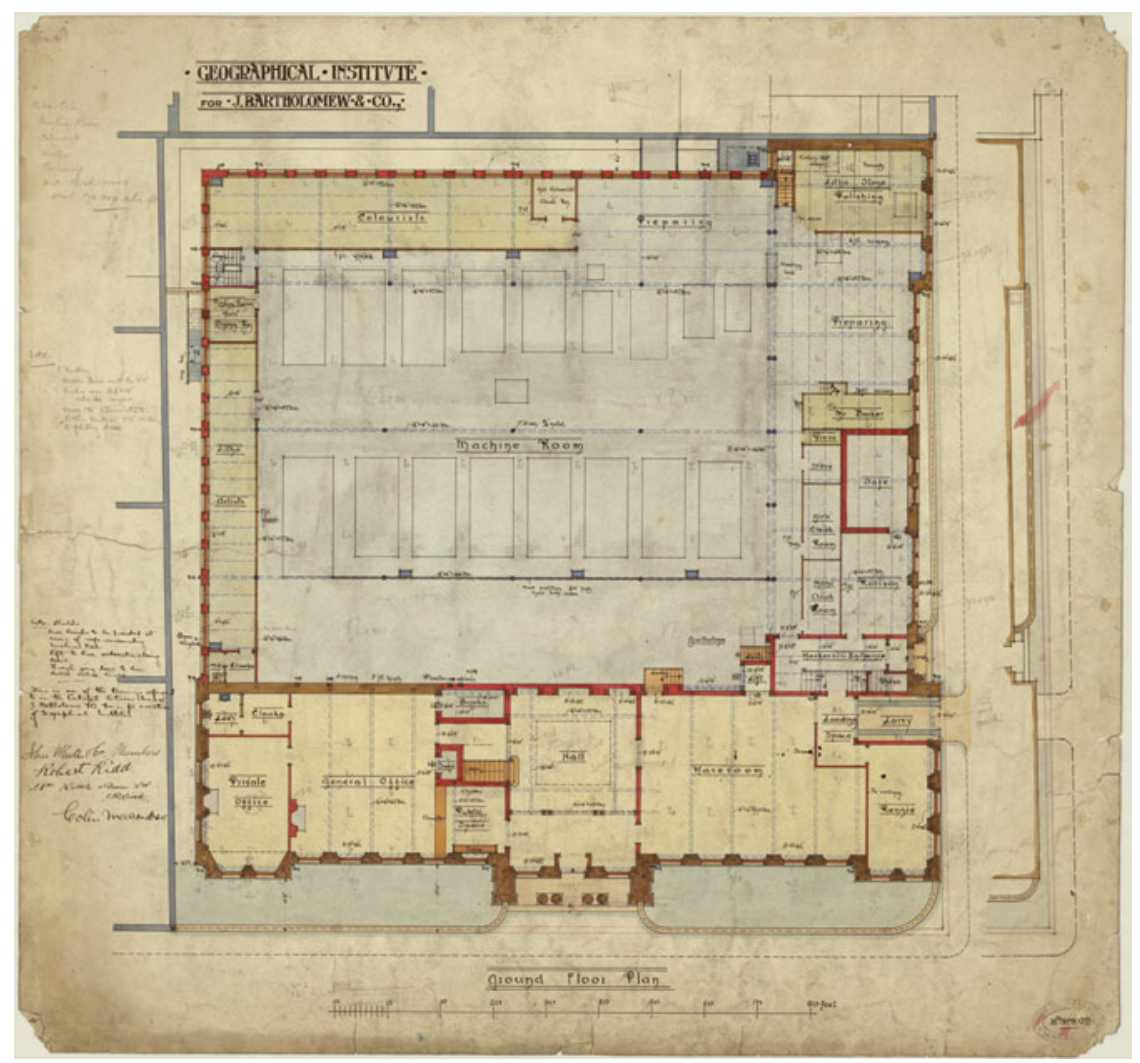

Figure 4: (Colour online) Floor plan showing the ground floor of Duncan Street premises. The public entrance to the building is on Duncan Street and the workers' entrance is around the corner to the right, on South Gray Street.

Source: National Library of Scotland, Acc.10222/BR/261, documents relating to Duncan Street premises. Reproduced with permission of HarperCollins Publishers.

Street. In fact, the height of the building at Duncan Street - it occupied three storeys, and had basement storage - gave Bartholomew substantially more space than they had occupied in previous premises. Increased space and a changed layout altered employees' experiences of working for the firm. Embodied experiences of sites could have a direct influence on the circulation of knowledge, especially in terms of the ease and comfort with which it could be absorbed. ${ }^{34}$ In this case, specific features also shaped employees' activities and thus the nature of Bartholomew's output.

34 D.A. Finnegan, 'Placing science in an age of oratory: spaces of scientific speech in midVictorian Edinburgh', in Livingstone and Withers (eds.), Geographies of Nineteenth-Century Science, 158. 
At Parkside, all rooms had windows on just the east side, and the shape of the building meant rooms were long and narrow, opening onto one long back corridor. At Duncan Street, all working spaces had increased light, whether natural or electrical (the latter was installed by the firm at a cost of around $£ 990$, the equivalent of around $£ 99,940$ in 2017). ${ }^{35}$ The building was also, as its larger scale necessitated, clearly internally organized, with separate departments occupying separate rooms and appropriate spaces given to certain types of task. Draughtsmen and engravers, for example, occupied much of the front of the first floor, and their large rooms had windows both to front and back. The provision of copious light reflected both the practical importance and the prestige of their work. ${ }^{36}$ They occupied a prime space on the first floor, next to the library and JGB's personal office. The noisy, heavy printing machinery was at the back of the ground floor, kept separate from the more expert processes carried out upstairs.

With its increased internal space and carefully delineated 'zones' of the building (such as quiet and loud), Duncan Street was clearly different to Parkside. The mode of circulation also differed between the two buildings. At Parkside, with its one long corridor, employees from different departments were likely to pass each other's rooms frequently. All employees entered through the machine room, as noted, and to get to his desk a draughtsman walked past not just the printers working in the machine room, but also stone polishers, lithographic artists, copperplate printers and engravers. ${ }^{37}$ This meant JGB, whose office was immediately adjacent to the entrance hall, was situated in a simultaneously public and private space. Though his office was the first room a visitor would have passed after walking through the entrance hall, it was also the least likely to have employees walking past during the course of the day. Here, the layout of the building renders the supposed dichotomy between public and private spaces complex: by placing himself in a public-facing position, JGB acquired more privacy from the day-to-day noise and business of his firm.

Although the circulation system at Duncan Street was more complicated, with multiple corridors and stairways, there was no obvious natural flow to the circulation as with Parkside's single corridor. Space had become more specialized, meaning employees were less likely to walk regularly

35 NLS, BA, Acc.10222/BR/260, Duncan Street papers, abstract of building account, 1909-11. 2017 prices calculated using 'project' calculation on Measuring Worth, www. measuringworth.com, accessed 12 Jun. 2018.

${ }^{36} \mathrm{G}$. Gooday, 'Instrumentation and interpretation: managing and representing the working environments of Victorian experimental science', in B. Lightman (ed.), Victorian Science in Context (London and Chicago, 1997), 425.

37 The gendering here is deliberate: draughting was carried out by an all-male team in this period. Gender roles in mapmaking are discussed in greater detail in the Ph.D. thesis from which this article originates. See A. Feintuck, 'Producing spatial knowledge: mapmaking in Edinburgh, c. 1880 - c. 1920', University of Edinburgh Ph.D. thesis, 2017. 
past other departments. Clearer demarcation of departments went handin-hand with a more straightforward relationship between public and private space. While still being the public face of the firm, JGB now occupied a relatively secluded space on the first floor, accessible only through the library or a long passageway. These changes to internal space dynamics meant that rather than necessarily taking place in his office, meetings could be conducted in any one of three spaces on the ground floor, all of which could be reached directly from the building's main entranceway. Elsewhere, too, the new scale of proceedings was reflected in the need for employees' provisions such as lavatories and cloakrooms on each floor. This change corresponds with a broader attention, nationally, to workers' day-to-day welfare. Moreover, this increasing complexity led to an increased need to document space in order to understand it and use it efficiently. ${ }^{38}$

The way these buildings were documented - in floor plans and insurance papers, for example - has importance that resonates beyond the boundaries of the premises themselves. The very act of recording a building's layout is meaningful. Creating a floor plan requires a systematic practice that is, in itself, telling. ${ }^{39}$ It suggests a need for precision, in order to use space effectively and, crucially, the privileging of this particular type of knowledge as a means of acquiring one's aims. In the case of insurance documents, precise knowledge - the focus of the following section allowed for the assessment of risk and thus supposedly increased financial security. ${ }^{40}$ This broadly follows the process of increasing 'abstraction and objectivity' visible in maps and urban planning in this period. ${ }^{41}$

This also applies to the technology found in the buildings. More advanced technical capability improved Bartholomew's ability to produce increasingly accurate and detailed maps. In printing, for example, the use of lithographic stones meant that, from the 1880s, multiple layers of colour could be printed, allowing for the development of now-standard contour layer colouring. But elsewhere, too, technology had a role to play. At Duncan Street, Bartholomew became one of the first businesses in Edinburgh to have internal telephone lines installed. In November 1910, they discussed the prospect with Glyde Chaffey \& Co., consulting electrical and mechanical engineers, who sent a list of rooms in the building that could have telephones installed. This would mean, the engineers told Bartholomew, 'that you could ring up any of the offices mentioned and give your instructions, and also that any of the offices mentioned could ring up any other offices and ask for any information

${ }^{38}$ Miller and $\mathrm{O}$ 'Leary, 'The factory as laboratory', 473.

39 Ibid.; P. Joyce, The State of Freedom: A Social History of the British State since 1800 (Cambridge, 2013), 33-4.

40 P. Fyfe, By Accident or Design: Writing the Victorian Metropolis (Oxford, 2015), 1-27, 100-24.

${ }^{41}$ Joyce, The Rule of Freedom, 195. 
regarding work they were required to $\mathrm{do}^{\prime}{ }^{42}$ Bartholomew were early adopters of the external telephone line - a letterhead from between 1900 and 1909 gave their telephone number as ' 611 Central' - so were aware of its advantages as a means of communication. Internal telephone systems would, as Glyde Chaffey \& Co. implied, speed up discussions between departments and could help to increase efficiency (and in turn potentially have a positive impact on income). They also had the potential to play a role in how the building was used and experienced. As discussed above, Duncan Street's layout resulted in fewer straightforward opportunities for workers to pass each other's departments than there had been at Parkside. The introduction of telephones further reduced the necessity and likelihood of circulation around the building, contributing to the broader trend of compartmentalizing departments and, consequently, delineating different areas of the premises. Conceptualizations of the building were likely to change accordingly, reinforcing this systematization: the allocation of different telephone numbers to different rooms made these spaces clearly separate entities. Furthermore, this additional means of communication required paper work of its own, such as lists of numbers and operation manuals, thereby increasing the overall complexity of the building's documentation.

In terms of physical production, there is a link between technology, premises and output. Buildings, by necessity, were adapted to accommodate changing processes, such as the introduction of heavier and more complex machinery. Improved facilities and a clearer layout had the potential to dictate the nature and quality of the maps produced in Bartholomew's properties across Edinburgh. Maps were, however, produced socially as well as physically. This section has also shown how the firm's awareness and use of both Edinburgh, as region, and specific elements of their properties, as site, constituted attempts to construct 'truth-spots'; that is, the belief that the knowledge emanating from these spaces was accurate. Nonetheless, this did not equate to the development of a 'placeless' image. The nature of their business was echoed in the design of their buildings. The neo-classical design of Duncan Street differentiated Bartholomew from other printers and publishers in the city by firmly emphasizing the intellectual nature of their business. Its internal layout showed the clear organization and demarcation of space, reflecting the firm's cartographic activities. The siting of their premises within Edinburgh shows an awareness of the link that could be forged between the reputation of a locality and their own credibility. The buildings served to demonstrate, physically and visually, the values the firm wished to convey, namely trustworthiness, respectability and intellectualism and this was done by embedding the firm's image in the local urban context, not by creating a sense of removal from it. Close attention to

42 NLS, BA, Acc.10222/BR/260, Duncan Street papers, letter from Glyde Chaffey \& Co., 2 Nov. 1910. 
premises, then, shows that JGB was aware of the importance of local, social and cultural factors in knowledge production and the construction of authority, and that he articulated the firm's chosen identity through careful production of space. This theme of social production continues into the following section, with a particular focus on collaborative urban knowledge.

\section{The conceptualization of urban space in Charles E. Goad's fire insurance plans}

Charles E. Goad (1848-1910) produced fire insurance plans of British cities from 1885. His company, Charles E. Goad Ltd, based in London, had covered most large British cities by the end of the nineteenth century. This section explores the collaborative mechanisms by which Goad became authorities on specific aspects of urban space in the late nineteenth and early twentieth centuries. Like Bartholomew, Goad's status determined the success of their plans (and vice versa). Status was constituted of 'credibility, authority, and expertise'.$^{43}$ Here, each of these constitutive parts is shown to have a local, spatial dimension, encouraging the development of a reputation of reliability and cartographic expertise. Locality, and social interaction within it, therefore continues to be a crucial constitutive part of the formation of authoritative cartographic knowledge - not a form of fallibility.

Fire insurance offices across Britain used Goad plans to inform their processes of risk evaluation and the consequent pricing of insurance policies. The plans show, primarily, the main industrial areas of cities and, through a system of colour-coding, symbols and abbreviations, provide a detailed picture of the buildings in the area (see Figure 5). Goad's team of surveyors examined the construction of walls, doors, passages, windows, floors, skylights, hoists and lifts, roofs and 'sundries' such as boilers, chimneys, fire alarms and hydrants. The development of the Goad plans came at a time when fires, and other urban accidents, were increasingly reported and commented upon; the expanding written discourse surrounding 'accidents' was a factor in growing concerns about understanding causation and risk. ${ }^{44}$ Certainly, fire was a prevalent occurrence in nineteenth-century cities, and this was undoubtedly a factor in the widespread use of Goad's work. In Edinburgh, for example, where 26 fire insurance companies subscribed to Goad's plans during the period in question, fire destroyed the premises of Thomas Nelson \& Sons in 1878 and those of Dobson, Molle \& Company, stationers, lithographers and printers in 1902. Further outbreaks damaged a paper-ruling factory and

43 S.J.M.M. Alberti, 'The status of museums: authority, identity, and material culture', in Livingstone and Withers (eds.), Geographies of Nineteenth-Century Science, 52.

44 For an overview of this idea see Fyfe, By Accident or Design, especially 10 and 25-7. 


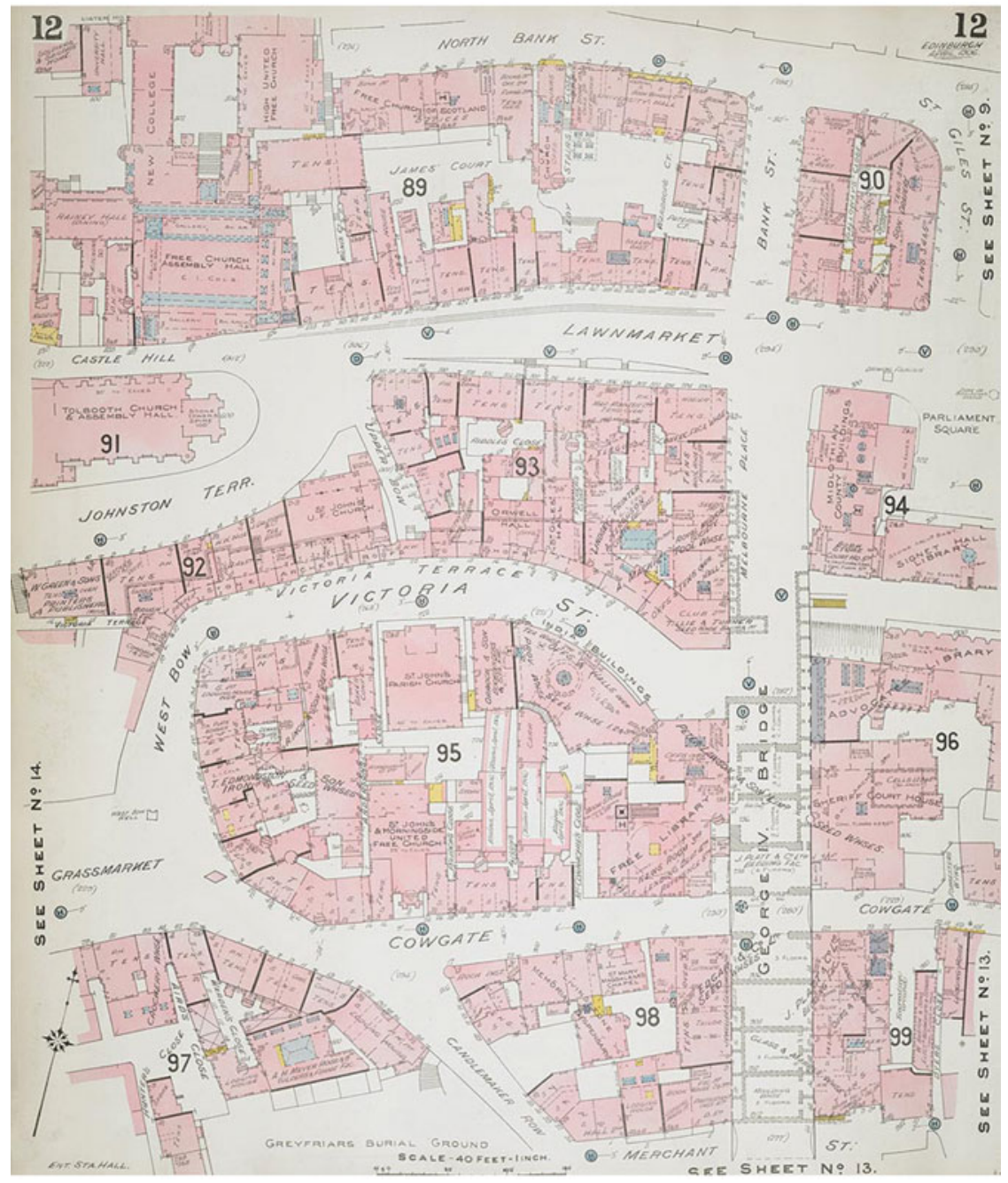

Figure 5: (Colour online) Charles E. Goad Ltd, Fire Insurance Plan of Edinburgh, sheet 12 (1906).

Source: British Library, Cartographic Items Maps 145.b.6.(1.).

Reproduced with permission of the British Library Board.

printing office off the High Street in 1910, and did 'considerable damage' to Parkside in $1916 .{ }^{45}$

45 British Library (BL), Maps GOAD.MSS, Plan Register, entries for Edinburgh. Reports on fires: 'The fire at Messrs Nelson \& Sons' printing works', The Scotsman, 12 Apr. 1878, 5; 'Destructive fire in Edinburgh: damage $£ 30,000$ to $£ 40,000$ ', The Scotsman, 21 Aug. 1902, 4; 
It should be noted, however, that Goad was neither the first nor the sole developer of fire insurance plans, though his firm rapidly dominated the market. In 1857, John Thomas Loveday produced the London Waterside Surveys for the Use of Fire Insurance Companies, which established conventions, later used by Goad, relating to colour-coding and the use of symbols. ${ }^{46}$ Loveday was employed by the Phoenix Assurance Company as a 'surveyor of risks', and published the London Waterside Surveys as an altruistic aside to his work for Phoenix. ${ }^{47}$ He believed these plans would 'materially lessen LABOUR, - encourage TIME, secure IDENTITY, and admit of UNIFORMITY OF $\overline{\text { ACTION', }^{\prime} \text { and that }}$ they also had the potential to 'facilitate that mighty engine of commercial prosperity'. ${ }^{48}$ The detailed information contained in the plans themselves is, of course, presented as highly useful, but their uniformity is arguably equally important for its influence on practice. The development of supposedly universal standards shows a belief in the power of conformity and of minimizing local variation. ${ }^{49}$ Goad, likewise, described the main benefit of his plans, for insurance companies, as the possession of some acknowledged data upon which to approximate a fair premium rate for the risk assessed'. ${ }^{50}$ By describing the data in his plans as 'acknowledged', Goad employed a 'legitimating rhetoric', implying that this information was accurate and - importantly - trusted and accepted. ${ }^{51}$ The subsequent publication of this information under Goad's name secured authorship, therefore, of facts acquired from a range of sources. The following sections explore these notions of knowledge production and circulation, with a focus on local, 'useful' - and, indeed, marketable - knowledge, and the implications of the Goad plans for broader conceptions of urban space in this period.

Goad made use of contemporary information when compiling plans. The 'Key Plan' to the Insurance Plan of Edinburgh (1892) gives the city's population as 267,000 , an increase of 5,775 from the 1891 census figure of $261,225 .{ }^{52}$ It is unclear, however, how the firm acquired this particular

'Alarming fire in High Street, Edinburgh', The Scotsman, 25 Oct. 1910, 6; 'Fire at Parkside Works, Edinburgh', The Scotsman, 22 Dec. 1916, 3.

46 P. Barber, London: A History in Maps (London, 2012), 229. Loveday's surveys are held in the BL: Cartographic Items Maps 4.b.1.

47 Barber, London.

${ }^{48}$ Loveday quoted in G. Rowley, British Fire Insurance Plans (Old Hatfield, 1984), 17. Emphases in original.

49 S. Schaffer, 'Metrology, metrication, and Victorian values', in Lightman (ed.), Victorian Science in Context, 440.

50 Goad quoted in Rowley, British Fire Insurance Plans, 23-4.

${ }^{51}$ Gieryn, 'City as truth-spot', 7.

52 BL, Cartographic Items Maps 145.b.6.(1.). Fire Insurance Plans of Edinburgh, 1892, Key Plan. The Census of Scotland shows Edinburgh's population was 261,225 in 1891 and 316,867 in 1901, meaning a steady rate of growth would see an increase of 5,561 per year: this is only 214 less than Goad's increase of 5,775, suggesting their figure is reasonably accurate. An equivalent calculation for the $1881(228,357)$ and 1891 census figures - in which a 10year increase of 32,868 implies annual growth of around 3,286 - would be less accurate 
statistic: earlier drafts of this plan give a different figure, which has a pencil annotation alongside it, requesting a correction and the use of census data. ${ }^{53}$ This shows a concern for precision and the provision of statistics commensurate with those of a reputable source. As discussed above, Charles Goad described the value of his plans in terms of their provision of 'acknowledged data'. Here, the firm made use of other 'acknowledged data' to reinforce the accuracy of their own information. Presenting methodologies as pre-established - in this case, by reference to the census - was a means of acquiring authority. ${ }^{54}$ Elsewhere, the firm collected 'masses' of newspaper cuttings relating to 'natural disasters such as fires and floods together with related notes'. ${ }^{55}$ They also kept a library of publications relating to contemporary fire safety engineering practices, including a number of collections of essays compiled by the British Fire Prevention Committee, which feature reports on experiments on specific aspects of buildings, such as comparative tests between door types. ${ }^{56}$ Goad's acquisition of these volumes reflects the contemporary cultural authority of experimentation as a means of establishing scientific fact. ${ }^{57}$ The broader processes of gathering information seen here are redolent of Bartholomew's method of cartographic 'compilation', in which the firm used extant maps, plans, reports and other documentation to draught their own material. The locally specific needs of Goad's clients, however, rendered this insufficient: unlike Bartholomew, they also had to survey the ground directly.

To produce plans for cities away from the firm's base in London, Goad gave instructions to a team of assistant surveyors who carried out the work and sent their findings back to London. ${ }^{58}$ Goad described this as 'field work' and often made reference to it in correspondence with insurance firms. Writing to G. Gillespie of the Northern Assurance Company, Edinburgh in 1904, regarding plans of Edinburgh and Leith, Goad explained: "the "field" work for these Revisions is now in hand, and I shall be pleased to receive your authority to add the name of your Company to the Subscription Lists'. ${ }^{59}$ At times, he also implied close personal involvement with these surveying practices, describing in 1900

if used to forecast population increase. This suggests Goad had access to demographic information other than published censuses.

53 BL, Maps GOAD.MSS Edinburgh Proof Maps, 1892, Key Plan.

54 Schaffer, 'Metrology, metrication, and Victorian values', 442.

55 Rowley, British Fire Insurance Plans, 22. Rowley conducted research in the Goad archive prior to its partial removal to the BL from the company's own stores. The BL's collection does not include these newspaper cuttings, but there is no reason to doubt Rowley's assertion that Goad gathered this material.

56 The British Fire Prevention Committee, Particulars of Experimental Fire Tests. Publication No. 39, ed. Edwin O. Sachs (London, 1900). This, along with six similar volumes, is held in the BL's collection of uncatalogued Goad material at Maps GOAD.MSS.

57 D. Gooding, T. Pinch and S. Schaffer, 'Introduction: some uses of experiment', in D. Gooding, T. Pinch and S. Schaffer (eds.), The Uses of Experiment (Cambridge, 1989), 5.

${ }^{58}$ Rowley, British Fire Insurance Plans, 43.

${ }^{59}$ BL, Maps GOAD.MSS, Letter Book AB, letter to G. Gillespie, 19 Jul. 1904, 30. 
how he had 'recently been carefully over the ground' in Glasgow's Kinning Park district in order to produce three additional sheets of the area. ${ }^{60}$ The firm's surveying practices were detailed: the finished plans show the level of local knowledge they amassed during the process of surveying, making it clear that surveyors went inside the buildings to assess the construction and state of floors, walls, windows and more. Evidence for these practices is shown, contrarily, by the firm's correspondence relating to occasions when access was refused to a building they wished to survey. Sheet 16 of the Edinburgh plans, for example, notes 'Admission refused, April 1906' above the 'Edinburgh Electric Lighting Sta'. ${ }^{61}$ The fact this is noted shows it is exceptional: clearly the norm was to be given access. Likewise, sheet 17 shows that the firm were also denied entry to the Royal Lyceum Theatre, though in this case the finished plan shows that they were evidently still able to gather significant detail about the building, such as its 'automatic alarms' and 'stone stairs'. ${ }^{62}$ One means of doing so was to make use of local knowledge and connections for negotiating. In July 1908, Goad wrote to a contact at the North British \& Mercantile Insurance Co. (hereafter NBM), Edinburgh:

In connection with the Revision of Edinburgh now in progress, one of my assistants advises me that this firm still refuses admission and 'will have nothing to do with us'. This is the firm about which you spoke to the writer in 1904 after you had seen the Proprietor, who did not seem to remember having refused admission. ${ }^{63}$

This letter makes it clear that Goad had a team of assistants working in various cities who kept in regular contact with him, even on a buildingby-building basis where necessary: his close personal involvement with the making of the plans is evident. It also shows that his customers played a role in the gathering of necessary information. In this case, his contact at NBM appears to have spoken to both the 'writer' (a member of Goad's team) and to the proprietor of the building in question - which, from consulting the relevant sheet of Goad's Fire Insurance Plan of Edinburgh (1892), was likely to have been 126 Princes Street, the only building on the street with no internal details given. ${ }^{64}$ It is unclear whether the contact at NBM was able to negotiate effectively prior to the revisions of $1906 .{ }^{65}$ Social relations are thus shown to be a vital constitutive part of the meaning and use of the final plan: Goad could not represent geographic realities in print without being granted access to them.

60 BL, Maps GOAD.MSS, Letter Book U, letter to P.R.D. Maclagan, 12 Jul. 1900, 205.

${ }^{61} \mathrm{BL}$, Goad's Fire Insurance Plans of Edinburgh, 1906, sheet 16. Cartographic Items Maps 145.b.6.(1.).

62 BL, Goad's Fire Insurance Plans of Edinburgh, 1906, sheet 17. Cartographic Items Maps 145.b.6.(1.).

63 BL, Maps GOAD.MSS, Letter Book AI, letter to G. Gillespie, 3 Jul. 1908, 436.

$64 \mathrm{BL}$, Goad's Fire Insurance Plans of Edinburgh, 1892, sheet 3. Cartographic Items Maps 145.b.6.(1.).

65 The BL's collection of Goad material does not include revision slips. 
The use of local knowledge was not limited to problem areas. Regarding the additional sheets of Edinburgh and Leith made available in 1906, Goad used the fact that they had 'been prepared after careful consultation with managers in Edinburgh' as a selling point. ${ }^{66}$ In 1912, too, Goad requested 'remarks' upon a draft tracing of the Bonnington Bonds in Leith from H.J. Scott of the Royal Insurance Co., Edinburgh, who duly obliged, facilitating the revision of the relevant sheet. ${ }^{67}$ This adds complexity to the relationship between the firm and its customers: it might be expected that the firm were the producers of knowledge, and that the customers were simply consumers, but in these three cases, at least - which are not presented as atypical - the customer played a significant role in the production processes.

Local knowledge, then, was a means of establishing accuracy. This gives insight into Goad's conceptualization of scale: obtaining this level of urban understanding was more plausible for individuals based permanently in the city. The acquisition and possession of local knowledge correspondingly built social credibility and trust by giving the customer agency relating to the nature of the finished product. Fire insurance offices outside of Edinburgh, whose staff had not necessarily directly experienced Edinburgh themselves, may have been more likely to trust their fellow insurers to provide Goad with the most pertinent information for the task at hand, allowing them to obtain knowledge 'by courtesy' ${ }^{68}$ As an 'interpretive community', the insurers gave meaning to the knowledge presented in Goad's plans, showing the importance of social connections and reputation. ${ }^{69}$ Broadly, this case may also indicate that Goad was especially in need of 'outsourced' local knowledge for cities a long way from London, which would make the northern British experience distinctive.

The finished product presented this urban knowledge in a codified and systematic manner. The index sheet of each published volume contains an 'Explanation of Signs used on Insurance Plans of Towns and Cities', which lists abbreviations, colour-coding and symbols used to describe the specificities of architectural features (see Figure 6). Goad provided additional cards containing the explanation of signs when companies requested them, and did not charge, writing simply in 1911 that these cards would hopefully 'increase the usefulness of the Plans' ${ }^{70}$ This system gives an insight into how these plans were read: in conjunction with the

66 BL, Maps GOAD.MSS, Letter Book AE, letters to H. Brown, J. Cowan, B. Bignold, J. Hamilton, F.W.P. Rutter and W.J. Vine, 1 May 1906, 370-5.

67 BL, Maps GOAD.MSS, Letter Book AR, letters to H.J. Scott, 7 Mar. 1912, 60, and 10 Mar. $1912,75$.

68 S. Shapin, 'Placing the view from nowhere: historical and sociological problems in the location of science', Transactions of the Institute of British Geographers, 23 (1998), 5.

69 C.W.J. Withers and D.N. Livingstone, 'Practices and performances', in Livingstone and Withers (eds.), Geographies of Nineteenth-Century Science, 150.

70 BL, Maps GOAD.MSS, Letter Book AP, letter to R. Wood Hawks, 18 Apr. 1911, 40. 


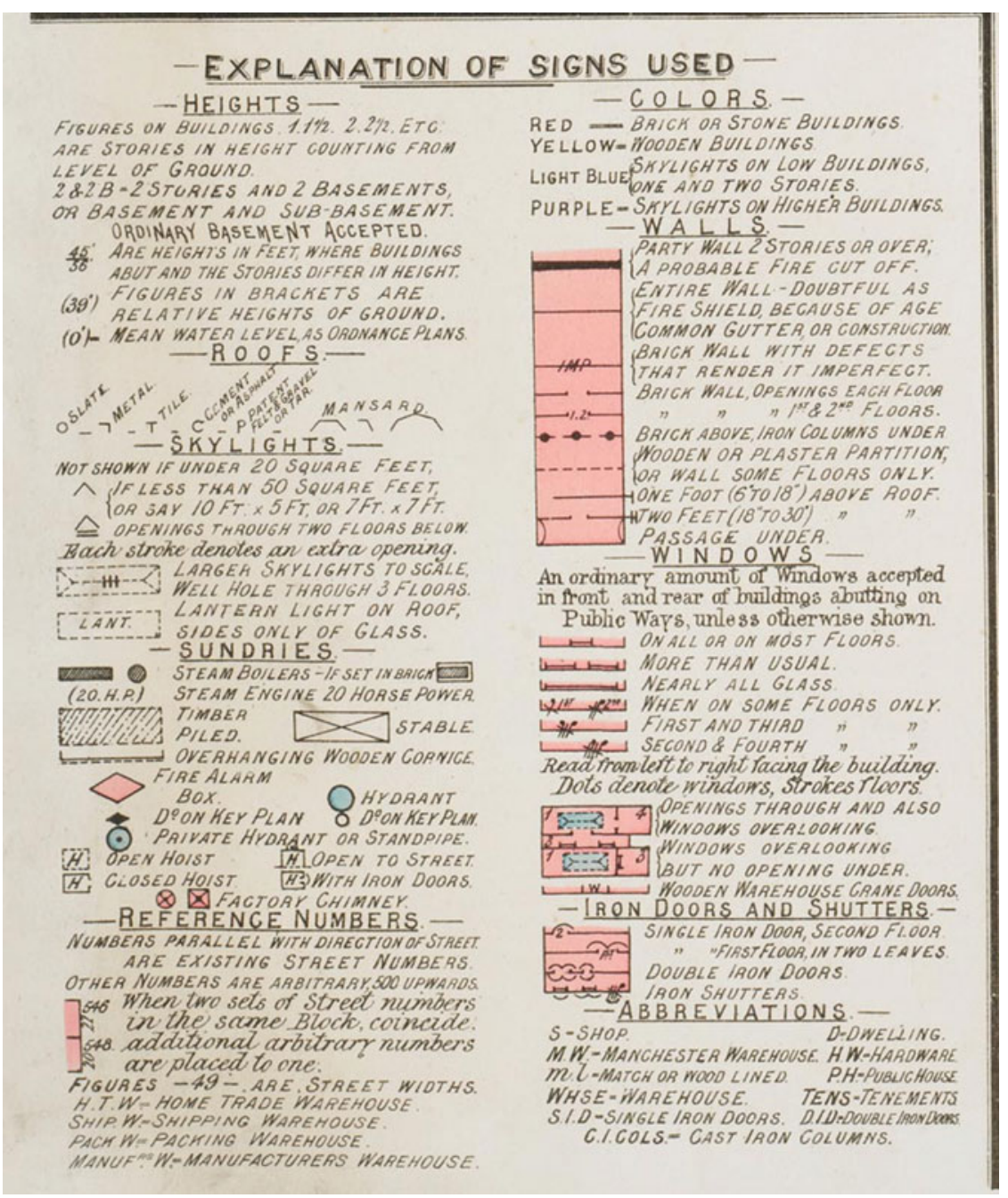

Figure 6: (Colour online) Charles E. Goad Ltd, 'Explanation of Signs Used'. This was sent to subscribing fire insurance companies, and was used consistently across the plans.

Source: British Library, Cartographic Items Maps 145.b.17. Reproduced with permission of the British Library Board.

explanation, a reader could reasonably quickly establish what a given building was made of and its internal composition, as well as gathering details about its surroundings.

The coding does not appear to have changed in the given period, suggesting that experienced users of the plans could have eventually 
learned to read them without needing to consult the explanation. The codification of knowledge here, then, is essentially a form of visual jargon, efficient and sufficient for those who understand it but potentially incomprehensible without the explanation. The explanation, however, removes much of the exclusivity of this knowledge. This example thus provides an insight into the notion of authoritative urban knowledge in this case, embodied in an insurer, who could 'read' the Goad plans in order to produce an informed policy - and the role of expertise. The development of 'objective' or standardized measurement more broadly in this period has been seen to remove the role of judgement and skill in actuarial sciences, for example. ${ }^{71}$ Here, though, skill is not about the acquisition of the information, which an educated non-specialist could also do if provided with the explanation of signs, but its interpretation. Goad did not ascribe levels of risk: this was left to the insurer's discretion. The plans thus provided companies with the means to exercise due skill and judgement. This, however, required actuarial skill along with knowledge of probability and valuation: professional skill evidently remained necessary.

Though this codified, systematic form of presenting urban knowledge was highly detailed on a micro (building-by-building) scale, in macro terms, city-wide coverage was not comprehensive. Plans of Edinburgh provide relatively thorough coverage of the central area of the city, encompassing premises between Princes Street and George Street; the length of Lothian Road; from George IV Bridge east to Canongate, and a small area close to Haymarket Station. They exclude, however, manufacturing districts such as that around Causewayside, where Bartholomew, along with a number of other printing and publishing establishments, were based. R. \& R. Clark's Brandon Street premises also fell outside Goad's coverage of the city, but records show they had a complex system of insurance, holding multiple policies acquired from NBM, the Law Union and Crown Union Insurance Company, and the Law Union and Rock Insurance Company Ltd, for which they provided minutely detailed accounts of the contents of each room of their premises. ${ }^{72} \mathrm{NBM}$, at least, certainly held copies of Goad's plans of Edinburgh, but in R. \& R. Clark's case, the particular location of the premises outside of the plans' coverage means that insurers must have made use of other forms of information in order to compile the policy. ${ }^{73}$

This omission shows that Goad's focus on what they deemed to be industrial areas of the city meant that the plans were not always comprehensive. In this respect, cities such as Edinburgh, not considered to be conventionally industrial, were disadvantaged: cities with heavy

71 T.L. Alborn, 'A calculating profession: Victorian actuaries amongst the statisticians', Science in Context, 7 (1994), 438.

72 NLS, Dep.229/101, R. \& R. Clark, insurance papers.

73 BL, Maps GOAD.MSS, Goad Plan Register, entries for Edinburgh. 
industry such as Manchester, Glasgow and Liverpool had significantly more complex coverage. ${ }^{74}$ This was a conscious decision on Goad's part, and coverage of specific industrial areas, heavy or otherwise, was often a selling point: in a letter from 1904, for example, persuading Allan Cook, Scottish Union National Insurance Co., to pay for additional volumes of London plans, he wrote: 'I notice that London VI is not in your list, and as I understand that this Vol. would be useful, I mention it lest it was omitted unintentionally; it is immediately to the north of Volumes I., II., III., and takes in the Cabinet-making district: Clerkenwell, Charterhouse, Old Street, St Lukes, Finsbury, \&c. ${ }^{75}$

Here, although smaller districts are named, the overall area is distinguished by its industry - 'the Cabinet-making district' - rather than being given a name or specific geographical descriptor. In Edinburgh, Goad produced plans of the city centre, Granton and Leith, giving a skewed geography of the city that, if the plans were viewed as a seamed whole, contained apparently blank areas. Despite their emphasis on the reasonably small-scale, skilled practice of cabinet-making in London, they neglected equivalent spaces in Edinburgh, such as the city's 'southside', as mentioned above, and the area around Leith Walk - the mapping of Leith and Edinburgh showed the two as wholly separate, ignoring this important linking road and its significant small-scale industry. The separation was formally accurate, prior to Leith's amalgamation into Edinburgh in 1920, but the urban 'border' was in fact highly fluid and permeable: Leith Walk provided an important flow between the two places. Goad's decision could have been influenced by the demands of insurers or his limited personal knowledge of the city. This dialectic relationship between Goad as producers and insurance companies as consumers therefore had the potential to play a role in influencing the development of 'zoning' in the city. Mapped areas were more quantifiable in terms of the fire risk posed by their buildings, which increased the ease with which they could be insured, and thus made these areas more desirable sites for industrial premises. From afar, Goad could be seen to have exercised some agency in more general urban development, whether deliberately or not. The firm would not have had the capacity to do so, however, without outsourced local knowledge.

Goad began producing plans in a period of rapid urban change, from the growth and consolidation of industry to increasing proportions of the population living in cities. Edinburgh was no exception to this: the population increased by 40 per cent between 1881 and 1911 (228,357 to 320,318). ${ }^{76}$ This widespread urban growth both necessitated and justified

74 Glasgow's coverage, by 1906, comprised 215 sheets, compared to Edinburgh (22), Leith (15) and Granton (2)'s combined total of 39.

75 BL, Maps GOAD.MSS, Letter Book U, letter to A. Cook, 20 Dec. 1904, 495. Emphases in original.

${ }^{76}$ Census of Scotland, population figures for 1891 and 1921. 
the development of the Goad plans. More specifically, the pace of change required the development of systematic revision procedures. As implied in much of the correspondence quoted above, Goad plans were regularly revised; their Edinburgh plans were updated every three years. ${ }^{77}$ In relative terms, this meant Goad plans were technically less up-to-date, though significantly more detailed, than the Post Office plans, which were revised annually, but that they were considerably more up-to-date than Ordnance Survey plans, which were revised at intervals of 10 to 30 years. ${ }^{78}$ Goad plans were revised through a system of 'correction slips'. Areas that had seen changes were re-drawn on slips of paper, which were pasted onto the original plan. The revision system itself resulted in a visible topography of change, whereby areas on the map requiring regular revisions became more built up in layers of paper over time, giving physical and cartographic form to the concept of the city as palimpsest.

The complexity of providing revisions justified the firm's policy of operating a subscription system, rather than selling the plans as individual items to be owned. Upon payment of an annual subscription fee, insurance companies would have their plans kept up-to-date, either by attaching revision slips themselves, or by sending their plans to Goad's London office to be updated in-house. The bulk of Goad's correspondence relates to revisions and negotiations over ongoing subscriptions. Though maintenance of the plans and running the subscription system was evidently time-costly, it allowed Goad a level of control over the use of their plans that they would not otherwise have had: they knew exactly who held each copy. ${ }^{79}$ Subscribers part-funded the production costs of each plan, which meant that they then had a vested interest in not sharing the information shown. Goad emphasized this in a statement attached to a number of volumes: 'Please see that plans in your possession are used solely for your company's business, not allowing Tracings or Copies to be made. Every company should bear its share in the expense of a common benefit. ${ }^{\prime 80}$ The specifics of this expense, however, were often negotiable: Goad proposed a 'very favourable offer' to companies who were 'prepared to extend their support appreciably' by paying, for example, for the use of second-hand copies of plans. ${ }^{81}$

The emphasis on the exclusivity of the plans - presented as a common benefit - necessitated, as described above, the development of close working relationships between Goad and the subscribing firms. This

77 BL, Maps GOAD.MSS, Letter Book AE, letter to R.W. Hawks, 18 May 1906.

78 C. Fleet and D. MacCannell, Edinburgh: Mapping the City (Edinburgh, 2014), 262; Feintuck, 'Producing spatial knowledge', 269-71.

79 BL, Maps GOAD.MSS, Goad Plan Register. This register lists all copies of the plans for each city alongside subscribing insurance firms, giving details of all dates of revision.

80 Goad quoted in Rowley, British Fire Insurance Plans, 37.

81 BL, Maps GOAD.MSS, Letter Book W, letter to J. Cowan, 28 Oct. 1901, 1. See also: Letter Book W, letter to J. Cowan, 18 Nov. 1901, 53; letter to T.S. Brown, 18 Mar. 1902, 329; letter to R. Cumming, 26 Mar. 1902, 393-4; Letter Book AB, letter to A. Cook, 20 Dec. 1904. 
meant that Goad regularly consulted branches before commencing work on new projects, to ascertain their potential use. In 1905, a company that made 'systematic use' of the plans contacted Goad suggesting that the absence of outline sheets, upon which memoranda could be made, for certain sheets of the Glasgow plans, 'causes much inconvenience'. Goad responded by contacting multiple existing subscribers - in Edinburgh, NBM and Century Insurance Co. (CI) - explaining this complaint, and stating 'I therefore propose preparing them and shall be glad to hear that you will accept them for your copies at the ordinary rate of $3 / 6$ each. ${ }^{\prime 2}$ P.R.D. Maclagan of NBM, along with other firms, declined to pay for the outline sheets; Goad consequently delayed printing, pending the acquisition of sufficient support. ${ }^{83}$ This shows the agency of individual firms in the operation and output of Goad's business, largely as a result of the subscription system. It also shows a consequent need for Goad to estimate likely rates of subscription prior to commencing production: his pool of potential subscribers was relatively small, by the very nature of the scale of the insurance industry, but subscriptions were still a more reliable source of income than selling, because they initiated continued revenue and, ideally, loyalty. Subscription represented commitment, and thus a level of projected trust in Goad's continuing cartographic expertise.

The language of mutual support seen across Goad's correspondence is interesting. It indicates, perhaps, that Goad perceived the plans as a project more than a profit-making business - or, indeed, presenting them as such may have been a particularly savvy business practice. Goad consistently requested 'support' when contacting firms speculatively to suggest they increase their subscriptions. This support was often presented as mutually beneficial. In September 1899, writing to James Cowan of CI, for example, Goad asked: 'As your support during this year...only amounts to $£ 18.10 .0$, can you kindly consider whether further subscription would not be of benefit to you as encouraging the maintenance of the work. ${ }^{84}$ Other letters took a similar tone. ${ }^{85}$ The relationship between producer and consumer is again highlighted here. Goad was quite explicit about the necessity of financial 'support' from the insurance offices to maintain the viability of producing the plans. In this respect, as with the seeking of local geographical knowledge, it is clear that insurance firms played an active role in shaping the precise operations of the company and the nature of output they consequently had access to. Requesting an increased annual subscription, Goad highlighted that these higher payments would be 'somewhat commensurate with the value of the work, if London is to

82 BL, Maps GOAD.MSS, Letter Book AC, letter to multiple recipients (in Edinburgh, NBM and CI), 27 May 1905, 428. The sheets in question were for plans of Glasgow: vol. 5, sheets 211 to 215.

83 BL, Maps GOAD.MSS, Letter Book AC, letter to P.R.D. Maclagan, 24 Jun. 1905, 496.

84 BL, Maps GOAD.MSS Letter Book T, letter to J. Cowan, 16 Sep. 1899, 111.

85 BL, Maps GOAD.MSS Letter Book T, letter to A. Duncan, 20 Sep. 1899, 138. 
be properly planned' ${ }^{86}$ He suggested that the quality of surveying and planning directly related to the sum paid by individual firms, alluding to their own interests. He also frequently compared the value of various firms' subscriptions and suggested to firms paying less that they come into line with others - in the spirit, it is implied, of fairness. ${ }^{87}$

The combination of regular revisions and a subscription system meant that a considerable volume of Goad's correspondence related to the maintenance of plans. Goad frequently pressured firms to keep their plans in a 'modern condition', and encouraged them to take into account 'how rapidly these Volumes become obsolete if the periodical Revisions are not attached'. ${ }^{88}$ In October 1908, one insurer declined Goad's offer of revisions to certain plans, saying they made little use of their current copies. Goad quickly responded: 'With reference to your copy of this volume which is held at your Glasgow Branch I can quite understand that it is hardly ever used, because reference to it would so frequently be found to be a waste of time by reason of the many changes which have taken place since it was last revised in 1895. ${ }^{\prime 89}$

In correspondence with other firms, he cautioned that 'plans which are not kept up to date naturally become distrusted, then fall into disuse, and the original outlay is lost sight of ${ }^{\prime}{ }^{90}$ Throughout, he demonstrated a keen awareness of the rapid changes taking place in British cities. Plans that were not up-to-date would be potentially useless. Evidently, it was in Goad's own interests for all plans to be kept current. Companies who carefully maintained their plans provided Goad with a consistent source of income. But he also commented that 'experience proves that unrevised Plans are far from satisfactory to those who use them, and do not assist the Reputation of the system generally'.$^{91}$ The mention of reputation here is key: insurance policies based on information from outdated plans would be potentially inaccurate, and although Goad would not be liable for this it was the insurance firms' own decision whether or not to update he nonetheless felt a vested interest in ensuring that firms claiming to use his information were, in fact, doing so as precisely as possible. The frequency with which they did so also had financial implications, but this was not the only consideration Goad took into account. In this case, Goad displayed genuine professional interest in accuracy alongside financial interest in obtaining regular income. Issues of accuracy were, in fact, further complicated by the lack of legal status surrounding notions of

86 BL, Maps GOAD.MSS Letter Book S, letter to C. Lee, 19 May 1899, 424.

87 Ibid.; see also BL, Maps GOAD.MSS Letter Book T, letter to A. Duncan, 20 Sep. 1899, 138; Letter Book W, letter to J. Cowan, 18 Nov. 1901, 53; Letter Book AF: letter to E.F. Newlands, 27 Oct. 1906, 375.

88 BL, Maps GOAD.MSS Letter Book AE, letter to J. Cowan, 23 Feb. 1906, 162.

89 BL, Maps GOAD.MSS Letter Book AH, letter to H. Brown, 8 Oct. 1907, 186.

90 BL, Maps GOAD.MSS Letter Book AI, letter to J.A. Cook, 6 Apr. 1908, 193.

91 BL, Maps GOAD.MSS Letter Book AF, letter to H. Brown, 15 Nov. 1906, 415. 
liability in this period. The concept of negligence was only introduced into Scots delict law in 1932, meaning that the use of inaccurate data was unlikely to implicate Goad in any sense other than a reputational one. Scientific reputation, however, 'hinged on cultures of communal trust', meaning the maintenance of relationships was crucial. ${ }^{92}$ It is evident, then, that Goad's impetus to achieve accuracy was motivated by concerns beyond legalities. He was aware that accuracy and reputation went handin-hand, and that local social factors were highly significant in the creation of both: interactions with customers were as important in establishing cartographic authority as were the details of the plans themselves. More broadly, though Edinburgh was a specific and distinctive case, Goad's use of the local as method was generalizable, and was applied to urban centres across Britain throughout this period and into the twentieth century.

\section{Conclusion}

This article demonstrates that the mechanisms used by cartographic firms in order to acquire credibility were inherently social and urban. Bartholomew and Goad each illustrate different aspects of the spatial and, specifically, local elements of knowledge production and circulation. When designing, building and working in their premises, Bartholomew used various tactics, all informed by an element of local knowledge, to ensure they embodied authority, which, by constructing a type of 'truthspot' within the city, played a role in imbuing their output with credibility. Rather than seeking universality and removing connections with place, though, Bartholomew's role as mapmakers meant they could embrace the supposed subjectivities of the local to demonstrate their expertise. Goad, by contrast, operated from a distance to acquire highly specific local knowledge, often through a network of 'expert' connections who knew the city well, in order to make their fire insurance plans authoritative and precise. For both firms, the end product was a map or plan, in which the city became the subject of knowledge. When the social nature of knowledge production is considered, however, the complexity of the city's role emerges. It serves as more than a mere setting for action. ${ }^{93}$ The individual and commercial reception of these representations of space was influenced by the acquisition of authority through localized, situated practices.

The Bartholomew material shows that the authority crucial to the reception of their cartographic products could be articulated - in part,

92 S. Schaffer, 'Accurate measurement is an English science', in M. Norton Wise (ed.), The Values of Precision (Princeton, 1995), 164.

93 S. Dierig, J. Lachmund and A.J. Mendelsohn, 'Introduction: toward an urban history of science', Osiris, 18 (2003), 1-19. 
at least - through careful curation of the built environment. In this, they often acted upon intuitive or tacit local knowledge. The decisionmaking processes involved in choosing a setting for their premises show a keen awareness of the meanings attached to various parts of the city; the fact that they chose to locate their first purpose-built premises in an area with a pre-existing reputation of being prosperous, rather than one in which they would be in close proximity to other, similar businesses, gives an insight into their priorities. Likewise, the design of the Duncan Street building, which mixed personal elements with a pareddown neo-classicism, articulated Bartholomew's identity as a professional, personable family firm. The practical elements of their business were notably ignored: the building was set in a predominantly residential area, with little indication from the outside that it housed light industrial activity. Inside, experiences of the building varied drastically depending on the person's status. Visitors saw spacious neo-classical grandeur, while the majority of employees, who stepped through a separate doorway, immediately entered busy and loud spaces. Bartholomew's desire to express their status as a firm dealing in knowledge, over and above the physical side of their work, is highlighted throughout. Emphasizing the intricate practices of mapmaking was not a priority: instead, a more general sense of grandeur, intellectualism and professionalism, along with attentiveness to locality, was employed to foster trust.

For Goad, local knowledge was key in order for their plans to acquire authority. From their base in London, the firm cultivated close working relationships with fire insurance companies throughout the country in order to obtain sufficiently detailed information about each city and thus produce accurate plans. The firm's customers therefore played a role in providing the information they were then expected to purchase: this appears to have influenced Goad's decision to present the plans as a collaborative effort, in which all companies bore their share 'in the expense of a common benefit'. ${ }^{94}$ This highly social, localized element of knowledge production thus aided precision and encouraged trust. Like Bartholomew, the success of their maps relied on their accuracy - and, in both cases, accuracy was, in part, a socially constructed value, and one that could be emphasized through close attention to local practices. A focus on the spatial dimensions of knowledge production, therefore, provides an insight into both firms' own conceptualization and use of urban space in the construction of cartographic authority.

The relationship between the map and the city was evidently dynamic and mutually beneficial. Cartography is shown here to benefit from an urban setting in a practical sense: networks, institutions, associations and a skilled labour market were all crucial to both firms' development. In a more abstract sense, Bartholomew in particular were able to use aspects of

${ }^{94}$ Goad quoted in Rowley, British Fire Insurance Plans, 37. 


\section{Urban History}

Edinburgh's existing reputation as a cultural, intellectual city to construct a similar image for themselves. The city, in turn, was made more legible and governable by increasingly detailed and accurate mapping. The map and the city should thus be seen to operate in a dialectic and fluid relationship, each shaping the other. 